ticles on electron microscopy. In this infant a good nasopharyngeal or tracheal aspirate might have enabled us to identify the virus and start antiviral treatment more rapidly. In retrospect, cervical or vaginal swabs from the mother taken specifically for viral culture might have led to an earlier diagnosis.

This case highlights some of the difficulties in the early diagnosis of herpes simplex infection in the newborn. In most affected infants the infection in the mother is unrecognised and at presentation only a third of infants with generalised disease have mucocutaneous lesions. In infants who seem to have a bacterial infection but fail to respond to antibiotics, evidence of herpes simplex virus must be actively sought.

We thank Drs Mona Elmahallawy. R P A Rivers and D Jeffrics for their assistance. T Lissauer is supported by Action Research, National Fund for Research into Crippling Diseases.

\section{References}

' Rand RJ. Genital herpes. Arch Dis Child 1983;58:575-6.

2 Nahmias AJ, Keyserling HL, Kerrick GM. Herpes simplex. In: Remington JS. Klcin JO, eds. Infectious diseases of the fetus and newborn infant. Philadelphia: W B Saunders, 1983.

${ }^{3}$ Whitley RJ and the NIAID Collaborative Antiviral Study Group. Interim summary of mortality in herpes simplex encephalitis and neonatal herpes simplex virus infections: vidarabine versus acyclovir. J Antimicrob Chemother 1983;12:Suppl B,105-12.

4 Visintine AM, Nahmias AJ. Whitley RJ, Alford CA. The natural history and epidemiology of neonatal herpes simplex virus infection. In: Nahmias AJ. Dowdlc WR. Shinagi RF, eds. The human herpes viruses. New York: Elsevier, 1980:Appendix 1:599-600.

s Arvin AM, Yeager AS, Bruhn FW, Grossman M. Neonatal herpes simplex infection in the absence of mucocutaneous lesions. J Pediatr 1982:100:715-21.

Correspondence to Dr T J Lissauer. St Mary's Hospital Medical School. Praed Strect, London W2 1PG.

Reccived 9 February 1984

\title{
Betaxolol and propranolol in glucagon stimulation of growth hormone
}

\author{
M COLLE, J BATTIN, J P COQUELIN, AND P ROCHICCIOLI
}

Children's Hospital, Bordeaux, Department of Paediatrics and Genetics, Rangueil University Hospital, Toulouse and LERS, Paris, France

SUMMARY Both betaxolol and propranolol, beta blockers with different pharmacological properties, increase the reliability of somatotropic testing with glucagon. The combination of glucagon and betaxolol, however, is much better tolerated than that of glucagon and propranolol. The use of a beta cardioselective adrenoceptor block for growth hormone testing is recommended.

A large number of growth hormone stimulating tests are used in children. One of the safest and most practical is the glucagon test but the discovery of non-responders to this test ${ }^{1}$ has resulted in the use of propranolol as an adjunct. ${ }^{2}$ Although this drug enhances the growth hormone response to glucagon by blocking the central beta adrenoceptors, it also increases such side effects as fatigue, pallor, sweating, and malaise ${ }^{3}$ which may be a reflection of chemically induced hypoglycaemia. ${ }^{4}$ The alternative use of the cardioselective beta blocker, betaxolol (available in the UK as Kerlone) has been proposed because, unlike propranolol, betaxolol does not alter the time course of the metabolic response to insulin induced hypoglycaemia. ${ }^{5}$

\section{Patients and methods}

A total of 420 children presenting with retarded growth and scheduled for growth hormone testing were studied. Patients with hypopituitarism, established by two negative tests, were excluded from the study. There were 250 boys and 170 girls with a mean age of 10.9 years (range 18 months to 16 years). The height of children included in the study was more than two standard deviations less than the age based norm.

The trial was designed as an open study comparing the safety and reliability of growth hormone testing in three parallel groups of children tested with glucagon only $(n=70)$, propranolol and glucagon $(n=125)$, or betaxolol and glucagon $(n=225)$. Informed parental consent was obtained.

Venous blood was drawn $90,120,150$, and 180 minutes after an intramuscular injection of $1 \mathrm{mg}$ of glucagon (glucagon only group) together with oral administration of propranolol $(1 \mathrm{mg} / \mathrm{kg}$ ) (proprano- 
Table Peak plasmagrowth hormone $(G H)$ concentrations, incidence of false negative findings, and side effects with the three test procedures

\begin{tabular}{lllll}
\hline Test & $\begin{array}{l}\text { No of } \\
\text { patients }\end{array}$ & $\begin{array}{l}\text { Peak plasma } \\
\text { (HH (ng/ml) } \\
\text { Mean }(\mathrm{S} D)\end{array}$ & $\begin{array}{l}\text { False } \\
\text { negative } \\
\text { results } \\
(\%)\end{array}$ & $\begin{array}{l}\text { Side } \\
\text { effects } \\
(\%)\end{array}$ \\
\hline $\begin{array}{l}\text { Glucagon only } \\
\begin{array}{c}\text { Propranolol } \\
\text { and glucagon }\end{array}\end{array}$ & 125 & $21.5(12.0) *$ & 16.5 & 0 \\
$\begin{array}{c}\text { Betaxolol } \\
\text { and glucagon }\end{array}$ & 225 & $30.7(11.2)^{*}$ & 4.0 & 8 \\
\hline
\end{tabular}

"No significant difference when compared with the two other procedures Conversion-traditional units to $S /$ : growth hormone $1 \mathrm{ng} / \mathrm{ml} \approx 0) \cdot(05 \mathrm{nmol} / \mathrm{l}$.

lol and glucagon group) or betaxolol $(0 \cdot 25 \mathrm{mg} / \mathrm{kg})$ (betaxolol and glucagon group). The plasma growth hormone concentration was measured by radioimmunoassay in each blood sample.

The effectiveness of growth hormone stimulation was judged on the basis of the highest recorded plasma growth hormone concentration. According to previous data, the growth hormone reserve was considered normal if a concentration greater than $0.47 \mathrm{nmol} / \mathrm{l}(10 \mathrm{ng} / \mathrm{ml})$ was found in at least one of the four blood samples. ${ }^{6}$ When the plasma growth hormone concentration was less than this in all blood samples an arginine and insulin test was performed and a false negative result was declared in the case of discordance.

Changes in heart rate and blood pressure and symptoms of hypoglycaemia were carefully recorded. Clinical events interfering with the completion of the test procedure such as bradycardia or hypoglycaemia, or both, justifying administration of atropine and glucose infusion, were counted as side effects.

\section{Results}

The results of the study are presented in the Table.

\section{Discussion}

The quality of a growth hormone testing method may be estimated in terms of the maximum growth hormone concentration achieved and the rate of false negative findings, but the reliability of the test should not be ensured at the expense of safety. The plasma growth hormone peak recorded with the betaxolol-glucagon procedure (mean (SD) 1.24 $(0 \cdot 49) \mathrm{nmol} / \mathrm{l}(26 \cdot 3(10 \cdot 5) \mathrm{ng} / \mathrm{ml}))$ was somewhat lower than that found with propranolol-glucagon $(1.44(0.53) \mathrm{nmol} / \mathrm{l}(30.7(11.2) \mathrm{ng} / \mathrm{ml}))$ but was quite sufficient to affirm the adequacy of the growth hormone reserve. The rate of false negative findings was much lower with both betaxolol-glucagon $(5.8 \%)$ and propranolol-glucagon $(4 \%)$ than with glucagon only $(16 \cdot 5 \%)$. Virtually no side effects were reported in the 225 tests using betaxololglucagon. This is to be compared with reported side effects in $8 \%$ of tests using propranolol-glucagon, in which symptoms of hypoglycaemia and bradycardia interfered with the completion of the test procedure.

The coadministration of a beta blocker and glucagon in this study improved the reliability of growth hormone test results by reducing the number of false negative findings. The enhancement of glucagon induced release of growth hormone is probably due to central beta adrenoceptor blockade. It thus seems worthwhile to use a beta blocker as an adjunct when glucagon stimulation is used for growth hormone testing in children. In the present study, the incidence of side effects with the propranolol-glucagon test corroborated the findings of other investigators who have urged caution in its use $;^{4}$ the betaxolol-glucagon test was, however, as well tolerated as glucagon alone.

The excellent safety record of betaxolol in this study may be related to the characteristics of the

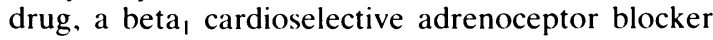
which seems to be metabolised differently from propranolol. Thus, Saunders et al showed that recovery from insulin induced hypoglycaemia was appreciably slower with propranolol than with betaxolol or placebo. ${ }^{5}$ Furthermore, the fact that the growth hormone concentration increased before hypoglycaemia was noted in betaxolol treated subjects, suggested a direct effect of betaxolol on growth hormone response, indicating that the beta receptors may have a role in this response. ${ }^{5}$ The betaxolol-glucagon test seems to offer a safety advantage over the propranolol-glucagon test and is therefore recommended for growth hormone testing in children with growth retardation.

\section{References}

1 Cain JP. Williams GH. Dluhy RG. Glucagon stimulation of growth hormone. J Clin Endocrinol Metab 1970:31:222-5.

2 Mitchell ML. Suvunrungsi P. Siwin CT. Effect of propranolol on the response of serum growth hormone to glueagon. J Clin Endocrinol Metab 1971:31:470-5.

3 Parks JS. Amrhein JA. Vaidya V. Moshang T. Bongiovanni AM. Growth hormone responses to propranolol-glucagon stimulation. A comparison with other tests of growth hormone reserve. J (lin Endocrinol Metab 1973;37:85-92.

+ Pelsor DA. Winter RJ. Green OC. Propranolol-induced hypoglycacmia during growth hormone testing. J Pediatr 1981:99: $157-8$.

5 Saunders J. Gomeni R. Kilborn JR. Morselli PL. Sonksen PH. A comparison between propranolol, practolol and betaxolol (SL 75212 ) on the circulatory and metabolic responses to insulininduced hypoglycaemia. Eur J Clin Pharmacol 1981:21:177-84. 
- Rochiccioli P. Enjeaume P. Dutau G. Ribot C. Augier D. Stimulation par le test propranolol-glucagon de la sécrétion somatotrope chez 71 enfants. Résultats. étude statistique et comparaison avec le test insuline-arginine. Arch Fr Pediatr 1976:33:453-65.
Correspondence to Dr M Colle. Clinique des Maladies des Enfants, Hôpital des Enfants. 168 Cours de l'Argonne, 33077 Bordeaux. France.

Received 12 February 1984

\title{
Two hundred glass injuries
}

\author{
D BELL
}

Accident and Emergency Department, Children's Hospital, Sheffield

SUMmary Two hundred children with glass injuries were investigated: 48 were injured in falls through architectural glass and 87 by broken bottles. Nine children had serious lacerations-7 of which were sustained at home. Radiographs were important in diagnosing retained fragments but prophylactic antibiotics were unnecessary. Many injuries could have been prevented by more stringent safety measures.

\section{Patients and methods}

Details of 200 consecutive glass injuries sustained by children attending this accident and emergency department were recorded from May to December 1981 with the help of a proforma. Glass injuries comprised $1.1 \%$ of new attendances in that period; most (124) occurred between July and September, with only 24 in May and June, 28 in October, and 24 in November and December. There were a few more boys $(55 \%)$ than girls. Twenty per cent were aged 0 to 4 years, $47 \%$ were aged 5 to 11 years, and $33 \%$ were aged 12 to 16 years. Forty seven per cent of the accidents occurred at home, $20 \%$ in the street, $12 \%$ in official play areas, $4 \%$ at school and $17 \%$ occurred elsewhere-in old houses, on waste ground, and in river heds and paddling pools. Forty three per cent of the children cut themselves on broken bottles and $25 \%$ fell through glass doors or windows. Others injured themselves on drinking glasses, glass furniture, mirrors, ornaments, and garden cold frames.

\section{Results}

Most (183) injuries were superficial lacerations treated in the accident and emergency department by cleaning and primary closure. Two children presented with localised abscesses resulting from minor wounds sustained some weeks earlier: these were incised under general anaesthetic and glass fragments were removed. One child was given flucloxacillin. Two children had bitten glass ornaments and swallowed tiny fragments without sustaining injury.

Thirteen children were referred elsewhere. Two were seen in surgical outpatients with transient problems after minor wounds. Two teenagers with minor injuries were admitted for social reasons-a disturbed girl who slashed her arms after absconding from a psychiatric unit and a boy who cut himself after a drinking bout.

Nine children injured themselves seriously, 7 at home. Three of the 7 fell through glass doors, a 2 year old girl sustained a deep cut to her upper lip, a 15 year old girl severed tendons and digital nerves of three fingers, and a 12 year old girl cut a wrist tendon. Two children cut themselves on panes of glass left lying about-a 14 year old boy who severed his Achilles tendon and a 9 year old boy who divided a finger tendon. Four injured themselves on other objects-a 2 year old boy fell on to a drinking glass and cut his thumb metacarpo-phalangeal joint capsule and digital nerve, an 11 year old boy severed finger tendons on a bottle, an 8 year old boy divided his right index finger flexor tendon on a jar while fishing, and a 7 week old baby sustained a penetrating injury to his left eye when a breast pump smashed and showered his face with glass.

Three injuries were repaired under local anaesthetic by the surgeons but 6 children (including the baby, who required corneal sutures) were admitted for general anaesthetic. Three needed further operations. Four wounds healed without complications but two children needed intensive physiotherapy to restore full finger movements. One child sustained corneal scarring and one facial scarring. One child was awaiting a third operation a year after his injury to improve right index finger function. Several children missed schooling during outpatient and physiotherapy visits subsequent to their injuries. 